\title{
PENGARUH BRAND IMAGE DAN KUALITAS PELAYANAN PEGAWAI TERHADAP KEPUASAN PELANGGAN PADA WARNET DIMENSI PEMATANGSIANTAR
}

\author{
Oleh: \\ Onita Sari Sinaga \\ S1 Manajemen \\ Darwin Lie, Marisi Butarbutar, Julyanthry
}

Abstraksi

Adapun rumusan masalah penelitian ini adalah bagaimana pengaruh brand image dan kualitas pelayanan pegawai terhadap kepuasan pelanggan pada Warnet Dimensi Pematangsiantar. Desain penelitian yang digunakan adalah penelitian kepustakaan dan penelitian lapangan. Jenis data yang digunakan adalah data kualitatif dan kuantitatif. Sumber data dalam penelitian ini adalah data primer dan data sekunder. Populasi dalam penelitian ini adalah pelanggan Warnet Dimensi Pematangsiantar berjumlah 750 orang. Pengumpulan data dilakukan dengan wawancara, kuesioner dan dokumentasi. Teknik analisis yang digunakan adalah regresi linier berganda, koefisien korelasi, koefisien determinasi, dan pengujian F serta t.

Hasil penelitian dapat disimpulkan sebagai berikut: 1. Brand image dan kualitas pelayanan pegawai sudah baik, dan kepuasan pelanggan juga dikategorikan puas. 2. Hasil regresi adalah $\hat{Y}=23,022+0,204 X_{1}+0,475 X_{2}$, artinya brand image dan kualitas pelayanan pegawai berpengaruh positif terhadap kepuasan pelanggan. 3 . Hasil koefisien korelasi diperoleh nilai $\mathrm{r}=0,546$ artinya terdapat hubungan yang sedang dan positif antara brand image dan kualitas pelayanan pegawai dengan kepuasan pelanggan. 4. Diperoleh nilai koefisien determinasi $R=0,298$ artinya tinggi rendahnya kepuasan pelanggan dapat dijelaskan oleh brand image dan kualitas pelayanan pegawai sebesar 29,8\%. 5. Hipotesis penelitian $\mathrm{H}_{0}$ ditolak, artinya brand image dan kualitas pelayanan pegawai berpengaruh positif dan signifikan terhadap kepuasan pelanggan pada Warnet Dimensi Pematangsiantar baik secara simultan maupun parsial.

Adapun saran dari penelitian ini adalah: untuk meningkatkan brand image, sebaiknya Warnet Dimensi Pematangsiantar melengkapi sarana dan fasilitas yang dapat mendukung produk yang ditawarkan dan melakukan perawatan untuk fasilitas yang sudah tersedia. Untuk meningkatkan kualitas pelayanan pegawai, sebaiknya pemilik usaha memberikan pelatihan dan arahan pada pegawai mengenai komputer. Untuk kepuasan pelanggan, agar menyediakan fasilitas pendukung seperti gamepad dan mouse macro, perbaikan koneksi jaringan internet dan mengadakan diskon harga paket pada jam tertentu.

Kata Kunci: Brand Image, Kualitas Pelayanan Pegawai dan Kepuasan Pelanggan

\section{Abstraction}

As for this research problem formula is how brand image and employee's service quality influence to customer's satisfaction in Warnet Dimensi Pematangsiantar. This research was conducted using study literature and observation. The data used is qualitative and quantitative data. Sources of data in this study are primary data and secondary data. The population us this study is customers in Warnet Dimensi Pematangsiantar 750 people. The data are collected based on the interview, quisionary, and literature documentation technique. The analysis of technique used double linear, correlation coefficient, determination, and hypothesis evaluation $F$ dan t.

Research result can be concluded as follows: 1. Brand image and employee's service quality has been good, and customer's satisfaction of also categorized satisfied. 2. The results is $\hat{Y}=23,022+0,204 X_{1}+0,475$ $X_{2}$, meaning that there are positive influence between the brand image and quality employee's service quality to customer's satisfaction. 3. The correlation result of $r=0,546$ means that there is a positive and moderate relationship between brand image and employee's service quality to customer's satisfaction. 4 . The coefficient of determination $R=0,298$ means that the level of customer satisfaction can be explained by the brand image and employee's service quality 29,8\%. 5. The research of hypothesis $H_{0}$ is rejected, meaning that the brand image and the employee's service quality positive and significant impact on customer satisfaction in Warnet Dimensi Pematangsiantar both simultaneously and partially.

The suggestion from this study are: to improve the brand image, Warnet Dimensi Pematangsiantar should complement the infrastructure and facilities to support the products offered and do regular maintenance on any existing facilities.To improve the employee's service quality, owners should provide training and guidance to employees regarding computer. For customer's satisfaction, in order to provide facilities like gamepad and mouse macros, improved network connection and hold a discount price packages during limited hours.

Keywords: Brand Image, Employee's Service Quality and Customer's Satisfaction 


\section{A. PENDAhuluan}

1. Latar Belakang Masalah

Perkembangan teknologi informasi dan komunikasi yang semakin maju menjadi salah satu faktor pendorong pesatnya perkembangan dan ketatnya persaingan dunia usaha, baik usaha yang bergerak di bidang industri maupun jasa. Warnet merupakan salah satu usaha yang menawarkan jasa layanan bagi pelanggan yang membutuhkan fasilitas koneksi internet.

Warnet Dimensi Pematangsiantar merupakan salah satu usaha mikro yang bergerak di bidang jasa. Warnet Dimensi Pematangsiantar memberikan pelayanan kepada masyarakat umum yang membutuhkan fasilitas koneksi internet dan fasilitas pendukung lainnya seperti printer dan penjualan snack dan minuman.

Kepuasan pelanggan menjadi kunci keberhasilan dari sebuah usaha yang bergerak di bidang jasa. Pemilik usaha harus mampu melihat dan memenuhi kebutuhan pelanggan, dengan melakukan identifikasi secara rinci untuk melampaui harapan pelanggan bukan hanya sekedar memenuhi harapan pelanggan. Kepuasan pelanggan terkait dengan kualitas produk, service quality, emotional factor, dan kemudahan. Dari hasil pengamatan sementara penulis di Warnet Dimensi Pematangsiantar tingkat kepuasan pelanggan masih belum maksimal, karena masih adanya keluhan-keluhan dari pelanggan terkait dengan kelengkapan sarana untuk bermain games dan kualitas pelayanan. Hal ini menjadi perhatian Warnet Dimensi Pematangsiantar dengan menciptakan brand image yang baik dan memperbaiki kualitas pelayanan.

Brand image adalah salah satu faktor yang dapat meningkatkan kepuasan pelanggan. Brand image merupakan persepsi pelanggan menyangkut apa yang dipikirkan dan dirasakan ketika melihat atau mendengar suatu merek. Warnet Dimensi Pematangsiantar meningkatkan brand image sebagai upaya untuk mengelola kepuasan pelanggan dengan cara meningkatkan kualitas produk dan lebih memperhatikan citra pembuat (corporate image), citra pemakai (user image), citra produk (product image). Adapun fenomena brand image yang terjadi di Warnet Dimensi Pematangsiantar yaitu fasilitas ruangan yang disediakan Warnet Dimensi Pematangsiantar sudah lengkap seperti adanya Close Circuit Television (CCTV), tersedianya toilet dan kipas angin. Namun citra yang dimiliki masih kurang baik karena kualitas jaringan internet yang sering melambat. Meskipun demikian pelanggan tetap datang karena produk yang ditawarkan berfokus pada games terbaru.

Kualitas pelayanan juga memiliki kaitan yang erat dengan kepuasan konsumen. Secara umum kualitas merupakan dimensi global yang relatif tidak sensitif terhadap perbedaan segmen, jika ingin membangun total kepuasan pelanggan dalam jangka panjang, komitmen terhadap kualitas pelayanan akan memberikan timbal balik yang setimpal. Kualitas pelayanan yang baik terdapat lima dimensi di dalamnya yaitu bukti langsung (tangibles), kehandalan (reliability), daya tanggap (responsiveness), jaminan (assurances), dan empati (emphaty). Dari hasil pengamatan sementara penulis di Warnet Dimensi Pematangsiantar kualitas pelayanan pegawai masih kurang maksimal. Hal ini dikarenakan ruangan Warnet Dimensi Pematangsiantar yang kurang luas sehingga membuat sirkulasi udara pada ruangan kurang baik, masih kurangnya pengetahuan pegawai mengenai produk yang ditawarkan seperti sistem jaringan dan kerusakan komputer, dan pelanggan sering kali harus menunggu saat meminta bantuan kepada pegawai.

\section{Rumusan Masalah}

a. Bagaimana gambaran brand image, kualitas pelayanan pegawai dan kepuasan pelanggan pada Warnet Dimensi Pematangsiantar.

b. Bagaimana pengaruh brand image dan kualitas pelayanan pegawai terhadap kepuasan pelanggan pada Warnet Dimensi Pematangsiantar baik secara simultan maupun parsial.

\section{Tujuan Penelitian}

a. Untuk mengetahui gambaran brand image, kualitas pelayanan pegawai, dan kepuasan pelanggan pada Warnet Dimensi Pematangsiantar.

b. Untuk mengetahui pengaruh brand image dan kualitas pelayanan pegawai terhadap kepuasan pelanggan pada Warnet Dimensi Pematangsiantar baik secara simultan maupun parsial.

\section{Metode Penelitian}

Yang menjadi objek penelitian adalah pelanggan Warnet Dimensi Pematangsiantar. Lokasi Warnet Dimensi Pematangsiantar terletak di Jalan Sangnawaluh No. 5B, Kelurahan Siopat Suhu, Kecamatan Siantar Timur, Kota Pematangsiantar. Populasi adalah rata-rata jumlah transaksi per minggunya pada bulan April 2016. Maka jumlah populasi adalah 750 orang.

Adapun desain penelitian yang digunakan dalam penulisan skripsi ini adalah Penelitian Kepustakaan (Library Research) dan Penelitian Lapangan (Field Research). Teknik pengumpulan data yang dilakukan penulis dalam penelitian ini adalah berupa Kuesioner, Wawancara dan Dokumentasi. Jenis data yang digunakan dalam penelitian ini adalah jenis data kualitatif dan data kuantitatif. Hasil data yang diperoleh dari lapangan akan dianalisis secara deskriptif baik bersifat kualitatif dan kuantitatif.

\section{B. LANDASAN TEORI}

1. Manajemen Pemasaran

Menurut Lupiyoadi dan Hamdani (2006:6), manajemen pemasaran adalah suatu analisis, perencanaan, pelaksanaan, serta kontrol programprogram yang telah direncanakan dalam hubungan dengan pertukaran-pertukaran yang diinginkan terhadap pelanggan yang dituju untuk memperoleh keuntungan pribadi maupun bersama. Menurut Kotler dan Kevin (2007:6), manajemen pemasaran 
adalah sebagai seni dan ilmu memilih pasar sasaran dan mendapatkan, menjaga, dan menumbuhkan pelanggan dengan menciptakan, menyerahkan dan mengkomunikasikan nilai pelanggan yang unggul. Berdasarkan pendapat para ahli di atas, penulis mengambil kesimpulan bahwa manajemen pemasaran adalah suatu analisis, perencanaan, pelaksanaan, serta kontrol program-program yang telah direncanakan untuk menciptakan, membangun, dan mempertahankan pertukaran yang menguntungkan dengan pembeli dengan sasaran agar mencapai tujuan organisasi.

\section{Brand Image}

Menurut Setiadi (2003:180), brand image (citra merek) mengacu pada skema memori akan sebuah merek, yang berisikan interpretasi pelanggan atas atribut, kelebihan, penggunaan, situasi para pengguna dan karakteristik pemasar dan/atau karakteristik pembuat dan produk/merek tersebut. Sedangkan menurut Kotler dalam Tjiptono (2005: 156), citra merek sebagai seperangkat keyakinan, ide dan kesan yang dimiliki oleh seseorang terhadap suatu merek, karena itu sikap dan tindakan konsumen terhadap suatu merek sangat ditentukan oleh citra merek tersebut. Citra merek merupakan syarat dari merek yang kuat. Berdasarkan beberapa definisi para ahli di atas maka penulis menyimpulkan bahwa brand image adalah seluruh keyakinan, ide dan kesan yang dimiliki oleh seseorang terhadap satu merek perusahaan baik yang bergerak di bidang jasa maupun perusahaan yang menghasilkan produk. Menurut Sutisna dan Pawitra (2001:80), brand image memiliki 3 variabel pendukung yaitu: citra pembuat (corporate image), citra pemakai (user image), dan citra produk (product image). Menurut Davis dan John (2000:53), citra merek memiliki dua komponen yaitu: brand associations (asosiasi merek) dan brand personality (kepribadian merek). Dari uraian di atas, penulis dapat menyimpulkan bahwa faktor-faktor yang mempengaruhi brand image adalah corporate image (citra pembuat) persepsi pelanggan terhadap perusahaan pembuat barang/jasa, user image (citra pemakai) persepsi pelanggan pemakai barang/jasa, product image (citra produk) persepsi pelanggan terhadap suatu barang atau jasa.

\section{Kualitas Pelayanan}

Menurut Lewis dan Booms dalam Tjiptono (2008:85), kualitas pelayanan dapat diartikan sebagai ukuran seberapa bagus tingkat layanan yang diberikan mampu sesuai dengan ekspektasi pelanggan. Sedangkan menurut Wyckof dalam Tjiptono (2004:59), kualitas pelayanan adalah tingkat keunggulan yang diharapkan dan pengendalian atas tingkat keunggulan tersebut untuk memenuhi keinginan pelanggan. Dari beberapa definisi di atas, maka penulis menyimpulkan bahwa kualitas pelayanan adalah tingkat kemampuan perusahaan untuk memenuhi kebutuhan dan harapan pelanggan dengan memperhatikan ketepatan penyampaiannya untuk melampaui tingkat harapan pelanggan.
Menurut Parasuraman dalam Tjiptono (2004:70), dalam mengevaluasi kualitas pelayanan perusahaan yang dapat digunakan sebagai kerangka perencanaan strategi dan analisis, adapun dimensidimensi tersebut adalah sebagai berikut: bukti langsung (tangibles), kehandalan (reliability), daya tanggap (responsiveness), jaminan (assurance), dan empati (empathy). Sedangkan Sedangkan Menurut Lupiyoadi (2006 :182), terdapat lima dimensi kualitas pelayanan yaitu: tangibles atau bukti fisik, reliability atau kehandalan, responsiveness atau ketanggapan, assurance atau jaminan dan kepastian, dan empathy yaitu memberikan perhatian yang tulus dan bersifat individual atau pribadi yang diberikan kepada para pelanggan dengan berupaya memahami keinginan pelanggan. Dari kedua pendapat ahli di atas, maka penulis menyimpulkan bahwa dimensi kualitas pelayanan ada lima yaitu tangibles, reliability, responsiveness, assurances, empathy.

\section{Kepuasan Pelanggan}

Menurut Kotler (2005:70), kepuasan pelanggan adalah perasaan senang atau kecewa seseorang yang muncul setelah membandingkan antara kinerja (hasil) produk yang dipikirkan terhadap kinerja yang diharapkan. Menurut Sumarwan (2003:322), kepuasan pelanggan merupakan dampak dari perbandingan antara harapan pelanggan sebelum pembelian dengan yang sesungguhnya diperoleh pelanggan dari produk yang dibeli tersebut. Dari beberapa pengertian di atas, maka penulis dapat menyimpulkan bahwa kepuasan pelanggan adalah perasaan yang dirasakan pelanggan setelah membandingkan antara harapan dan kenyataan, sebelum dan sesudah memakai suatu produk atau jasa suatu perusahaan.

Menurut Lupiyoadi dan Hamdani (2006:192), ada 4 (empat) faktor utama yang harus diperhatikan dalam kaitannya dengan kepuasan pelanggan antara lain : kualitas produk atau jasa, struktur harga, kenyamanan prosedur, dan dukungan pelanggan. Sedangkan menurut Irawan (2002:37) ada lima faktor pendorong kepuasan pelanggan berdasarkan studi literatur dan pengalaman selama menjadi konsultan berbagai perusahaan di Indonesia yaitu: kualitas produk, harga, service quality, emotional factor, dan kemudahan. Berdasarkan uraian di atas dapat disimpulkan dengan mengetahui harapan pelanggan akan kualitas suatu produk atau jasa maka perusahaan harus memperhatikan faktor-faktor yang dapat mempengaruhi kepuasan pelanggan yaitu, kualitas produk, harga, service quality, emotional factor, dan kemudahan.

\section{PEMBAHASAN \\ 1. Analisa}

\section{a. Deskriptif Kualitatif}

Analisis deskriptif kuantitatif dimaksudkan untuk mendapatkan gambaran atau deskripsi mengenai tanggapan dari pelanggan mengenai pengaruh brand image dan kualitas pelayanan pegawai terhadap kepuasan pelanggan Warnet Dimensi Pematangsiantar. Adapun penetapan kriteria 
nilai rata-rata jawaban dari responden tersebut dimasukkan kedalam kelas-kelas interval dimana penentuan intervalnya memakai rumus sebagai berikut:

Interval Kelas $=\underline{\text { Nilai Tertinggi }- \text { Nilai Terendah }}$

$$
\text { Jumlah Kelas }
$$

Dari rumus di atas dapat diperoleh interval kelas 0,8 sehingga berlaku ketentuan indikator dengan hasil sebagai berikut:

Tabel 1

Nilai Interval dan Indikator Jawaban Responden

\begin{tabular}{|c|c|c|c|}
\hline \multirow{2}{*}{$\begin{array}{c}\text { Nilai } \\
\text { Interval }\end{array}$} & \multicolumn{3}{|c|}{ Indikator } \\
\hline $1,00-1,80$ & Komunikasi & Disiplin kerja & Kinerja Kerja \\
\hline $1,81-2,60$ & Sangat Tidak Baik & $\begin{array}{c}\text { Sangat Tidak } \\
\text { Baik }\end{array}$ & $\begin{array}{c}\text { Sangat Tidak } \\
\text { Baik }\end{array}$ \\
\hline $2,61-3,40$ & Cukup Baik & Tidak Baik & Tidak Baik \\
\hline $3,41-4,20$ & Baik & Baik Baik & Cukup Baik \\
\hline $4,21-5.00$ & Sangat Baik & Sangat Baik & Baik \\
\hline
\end{tabular}

Sumber : hasil pengolahan data

\section{1) Gambaran Brand Image Pada Warnet Dimensi Pematangsiantar}

Dari hasil analisa, untuk dimensi citra pembuat (corporate image) pada indikator popularitas Warnet Dimensi Pematangsiantar berada pada rata-rata 4,17 dengan kriteria jawaban baik. Hal ini disebabkan produk yang ditawarkan mendominasi pada games dan sudah pernah membuka cabang usaha di beberapa lokasi di Pematangsiantar. Demikian dengan indikator citra Warnet Dimensi Pematangsiantar berada pada ratarata 3,89 dengan kriteria jawaban baik. Hal ini disebabkan produk yang ditawarkan berbeda dengan warnet yang lain dan fasilitas ruangan yang disediakan untuk pelanggan sudah cukup lengkap seperti adanya kipas angin, toilet dan fasilitas keamanan. Pada indikator penilaian pelanggan terhadap Warnet Dimensi Pematangsiantar dengan kriteria jawaban baik rata-rata jawaban 3,90 hal ini disebabkan lengkapnya jenis games yang tersedia baik games online maupun offline, tersedianya jasa pendukung lainnya seperti printer dan adanya snack dan minuman

Demikian juga untuk dimensi citra pemakai (user image) pada indikator kesetiaan pelanggan terhadap Warnet Dimensi Pematangsiantar berada pada rata-rata nilai 3,89 dengan kriteria jawaban baik, hal ini disebabkan masih belum maksimalnya pelayanan pegawai dan masih kurangnya baiknya kualitas jaringan internet yang ditawarkan Warnet Dimensi Pematangsiantar. Pada indikator kepercayaan pelanggan terhadap Warnet Dimensi Pematangsiantar berada pada nilai rata-rata 3,93 dengan kriteria jawaban baik, dalam hal ini pelanggan memiliki rasa percaya yang cukup baik kepada Warnet Dimensi Pematangsiantar terutama terkait dengan pembayaran setiap transaksi. Pada indikator Warnet dimensi dalam mementingkan rasa aman pelanggan mendapat nilai rata-rata 3,92 dengan kriteria jawaban baik, hal ini disebabkan Warnet Dimensi Pematangsiantar mementingkan rasa aman setiap pelanggan dengan menyediakan tempat parkir dan memasang CCTV untuk mengantisipasi terjadinya pencurian.
Pada dimensi citra produk (products image) untuk indikator atribut produk yang ditawarkan dengan rata-rata 3,93 pada kriteria jawaban baik, hal ini disebabkan atribut produk yang ditawarkan Warnet Dimensi Pematangsiantar sudah baik sehingga selalu dapat menarik perhatian para pelanggan namun sarana pendukung untuk bermain games belum lengkap. Pada indikator kenyamanan yang diberikan Warnet Dimensi Pematangsiantar, dengan nilai rata-rata 3,96 pada kriteria jawaban baik. Hal ini disebabkan Warnet Dimensi Pematangsiantar selalu berusaha membuat pelanggan merasa nyaman dengan menjaga kebersihan ruangan dan memasang kipas angin. Pada indikator keamanan yang diberikan Warnet Dimensi Pematangsiantar, responden memberikan respon dengan nilai rata-rata 3,98 dengan kriteria jawaban baik. Hal ini dsebabkan pelanggan merasa fasilitas keamanan yang disediakan Warnet Dimensi Pematangsiantar sudah baik seperti adanya CCTV.

Secara keseluruhan dapat dilihat bahwa nilai rata-rata brand image yang diberikan responden berada pada 3,95 dengan kriteria jawaban baik. Nilai tertinggi 4,17 pada kriteria jawaban baik yaitu pada indikator popularitas Warnet Dimensi Pematangsiantar di masyarakat. Untuk nilai terendah 3,89 dengan kriteria jawaban baik pada dimensi citra pembuat (corporate image) pada indikator citra Warnet Dimensi Pematangsiantar, dan dimensi citra pemakai (user image) pada indikator kesetiaan pelanggan terhadap Warnet Dimensi Pematangsiantar.

\section{2) Gambaran Kualitas Pelayanan Pegawai Pada}

Warnet Dimensi Pematangsiantar

Dari hasil analisa, dapat dilihat bahwa dimensi bukti fisik (tangibles), indikator ketersediaan fasilitas penunjang seperti pendingin ruangan dengan nilai rata-rata 3,82 dalam kriteria jawaban baik. Dalam hal ini Warnet Dimensi Pematangsiantar menyediakan fasilitas kipas angin namun jumlah yang disediakan masih kurang. Pada indikator kondisi ruangan Warnet Dimensi Pematangsiantar berada pada rata-rata 3,90 dengan kriteria jawaban baik, karena kondisi ruangan yang tidak terlalu luas tetapi bersih dan dilengkapi dengan kipas angin. Pada indikator penampilan pegawai dengan rata-rata 4,06 pada kriteria jawaban baik, hal ini karena pegawai selalu berpakaian yang sopan saat bekerja.

Pada dimensi kehandalan (reliability), indikator pegawai dalam memberikan pelayanan yang dijanjikan dengan nilai rata-rata 3,87 pada kriteria jawaban baik. Hal ini disebabkan masih seringnya pelanggan harus menunggu untuk dapat menggunakan komputer karena terbatasnya jumlah komputer yang tersedia. Untuk indikator pegawai dalam menanggani masalah yang dihadapi pelanggan mendapat nilai rata-rata 3,75 dengan kriteria jawaban baik. Pelanggan sering tidak mendapatkan penyelesaian masalah dari pegawai, sebagian disebabkan karena kurangnya pengetahuan pegawai. Pada indikator waktu yang dijanjikan pegawai 
Warnet Dimensi Pematangsiantar dalam menyelesaikan transaksi dengan rata-rata 3,93 pada kriteria jawaban baik, hal ini terjadi karena pelanggan merasa puas dengan kecepatan pegawai dalam melayani pelanggan tanpa harus membuat pelanggan menunggu terutama dalam menyelesaikan transaksi pembayaran.

Pada dimensi daya tanggap (responsiviness), untuk indikator pegawai Warnet Dimensi Pematangsiantar dalam menjawab pertanyaan pelanggan dengan rata-rata 4,01 pada kriteria jawaban baik. Hal ini karena pegawai selalu bersikap baik dan tanggap saat menjawab pertanyaan pelanggan, baik yang berhubungan dengan jasa yang ditawarkan maupun hal lainnya. Pada indikator ketanggapan pegawai dalam menanggapi masalah pelanggan dengan nilai rata-rata 3,78 pada kriteria jawaban baik. Hal ini disebabkan pegawai masih lambat dalam menangani masalah pelanggan dan masih seringkali ragu dalam mnegambil kebijakan untuk membantu pelanggan. Pada indikator pegawai dalam merespon permintaan pelanggan dengan nilai rata-rata 3,80 pada kriteria jawaban baik, hal ini disebabkan pegawai sering kali sibuk dengan pekerjaannya sehingga terkadang tidak merespon permintaan pelanggan.

Pada dimensi jaminan (assurance), indikator pengetahuan yang dimiliki pegawai dengan nilai rata-rata 3,64 pada kriteria jawaban baik. Hal ini disebabkan pegawai masih belum mampu menangani masalah komputer jika terjadi kerusakan saat pelanggan menggunakan komputer. Pegawai tidak memiliki kemampuan dalam hal pengetahuan komputer baik secara teknis maupun nonteknis. Pada indikator keramahan pegawai Warnet Dimensi Pematangsiantar mendapat nilai rata-rata 4,02 pada kriteria jawaban baik, hal ini karena pegawai selalu bersikap ramah pada pelanggan yang datang. Pada indikator sikap pegawai Warnet Dimensi Pematangsiantar saat melayani pelanggan dengan rata-rata 3,93 pada kriteria jawaban baik, hal ini disebabkan pegawai selalu berusaha untuk bersikap baik kepada pelanggan dengan tujuan agar terjalin hubungan yang baik antara pegawai dengan pelanggan.

Pada dimensi empati (empathy), indikator sikap pegawai Warnet Dimensi Pematangsiantar dengan rata-rata 3,90 pada kriteria jawaban baik. Hal ini terjadi karena sikap pegawai selalu ramah dan sopan kepada semua pelanggan sehingga pelanggan tidak sungkan untuk bertanya maupun meminta tolong pada pegawai. Pada indikator komunikasi pegawai Warnet Dimensi Pematangsiantar dengan pelanggan dengan rata-rata 3,98 pada kriteria jawaban baik, hal ini terjadi karena pegawai sudah mampu berkomunikasi dengan baik pada pelanggan, namun hanya pada sebagian pelanggan yang mereka kenal. Pada indikator pegawai Warnet Dimensi Pematangsiantar dalam menanggani keluhan pelanggan dengan rata-rata 3,82 pada kriteria jawaban baik, hal ini terjadi karena pegawai sering mengabaikan keluhan pelanggan.

\section{3) Gambaran Kepuasan Pelanggan Pada Warnet} Dimensi Pematangsiantar

Dari hasil analisa, dapat dilihat bahwa pada dimensi kualitas produk dengan indikator pegawai Warnet Dimensi Pematangsiantar dalam memberikan penjelasan produk kepada pelanggan berada pada rata-rata 3,77 dengan kriteria jawaban puas. Hal ini disebabkan pegawai masih kurang mampu dalam memberikan penjelasan produk kepada pelanggan, karena kurangnya pengetahuan mengenai games yang tersedia. Selanjutnya indikator pegawai Warnet Dimensi Pematangsiantar dalam menjelaskan penggunaan fasilitas berada pada rata-rata 3,81 dengan kriteria jawaban puas, hal ini karena pegawai sudah mampu mennjelaskan penggunaan fasilitas seperti penggunaan headset. Untuk indikator penawaran produk Warnet Dimensi Pematangsiantar berada pada rata-rata 3,85 dengan kriteria jawaban puas, pelanggan sudah merasa puas dengan produk yang ditawarkan dan telah sesuai dengan keinginan pelanggan yaitu produk yang berfokus pada games online maupun offline dan adanya jasa pendukung lain seperti printer, snack dan minuman.

Pada dimensi harga dengan indikator paket harga pada Warnet Dimensi Pematangsiantar berada pada rata-rata 3,83 dengan kriteria jawaban puas, hal ini disebabkan harga paket yang ditawarkan terjangkau dan murah jika dibandingkan dengan warnet lain. Indikator harga yang ditawarkan Warnet Dimensi Pematangsiantar dengan apa yang pelanggan dapatkan berada pada rata-rata 3,90 dengan kriteria jawaban puas, hal ini disebabkan harga yang ditawarkan telah sesuai dengan manfaat yang didapatkan pelanggan. Untuk indikator harga yang ditawarkan Warnet Dimensi Pematangsiantar dibanding dengan warnet lain berada pada rata-rata 3,92 dengan kriteria jawaban puas, hal ini disebabkan harga yang ditawarkan kepada pelanggan relatif murah dan terjangkau sehingga pelanggan merasa puas.

Pada dimensi service quality dengan indikator pelayanan yang didapatkan pelanggan di Warnet Dimensi Pematangsiantar berada pada rata-rata 3,89 dengan kriteria jawaban puas, hal ini disebabkan pegawai melayani setiap pelanggan dengan baik tanpa membuat perbedaan antara pelanggan yang satu dengan yang lainnya. Indikator kenyamanan yang diberikan pegawai Warnet Dimensi Pematangsiantar berada pada rata-rata 3,92 dengan kriteria jawaban puas, hal ini karena pegawai sudah mampu memberikan kenyamanan pada pelanggan dengan selalu menjaga kebersihan ruangan dan memutar musik dengan volume yang sewajarnya. Indikator keamanan yang diberikan pegawai Warnet Dimensi Pematangsiantar berada pada rata-rata 3,95 dengan kriteria jawaban puas, karena pegawai selalu ikut serta berperan dalam menjaga keamanan pelanggan seperti menyimpan barang milik pelanggan yang tertinggal.

Pada dimensi emotional factor dengan indikator citra yang diciptakan pegawai Warnet Dimensi Pematangsiantar dimata masyarakat berada pada rata-rata 3,90 dengan kriteria jawaban puas, 
karena pegawai Warnet Dimensi Pematangsiantar selalu berupaya untuk membuat citra warnet tersebut baik di mata masyarakat seperti menghindari terjadinya perkelahian dengan pelanggan. Indikator tingkat kebanggaan yang dimiliki pelanggan terhadap Warnet Dimensi Pematangsiantar berada pada rata-rata 3,86 dengan kriteria jawaban puas, karena pelanggan sudah merasa bangga dapat bermain di Warnet Dimensi Pematangsiantar karena populer di masyarakat. Indikator standar pelayanan pegawai Warnet Dimensi Pematangsiantar berada pada rata-rata 3,85 dengan kriteria jawaban puas, karena standar pelayanan yang ada pada Warnet Dimensi Pematangsiantar sudah baik.

Pada dimensi kemudahan dengan indikator kelengkapan fasilitas pendukung bermain games di Warnet Dimensi Pematangsiantar berada pada ratarata 3,69 dengan kriteria jawaban puas, hal ini disebabkan masih adanya keluhan dari pelanggan terkait dengan fasilitas pendukung untuk bermain games masih belum lengkap. Indikator jaringan internet Warnet Dimensi Pematangsiantar berada pada rata-rata 3,59 dengan kriteria jawaban puas, hal ini disebabkan terkadang jaringan internet melambat dan terputus-putus. Indikator letak lokasi Warnet Dimensi Pematangsiantar berada pada rata-rata 4,18 dengan kriteria jawaban puas, hal ini karena letak lokasi warnet yang strategis dekat dengan jalan besar sehingga mudah untuk dijangkau.

\section{b. Deskriptif Kuantitatif \\ 1) Regresi Linear Berganda}

Untuk menganalisa pengaruh brand image $\left(\mathrm{X}_{1}\right)$ dan kualitas pelayanan $\left(\mathrm{X}_{2}\right)$ terhadap kepuasan pelanggan (Y) pada Warnet Dimensi Pematangsiantar secara bersama-sama. Dengan menngunakan bantuan program SPSS 20, didapatkan hasil regresi sebagai berikut:

Tabel 2

Hasil Regresi Linier Berganda Coefficients $^{\mathrm{a}}$

\begin{tabular}{|c|c|c|c|c|}
\hline \multirow{2}{*}{\multicolumn{2}{|c|}{ Kanal }} & \multicolumn{2}{|c|}{ 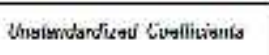 } & \multirow{2}{*}{ 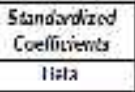 } \\
\hline & & & Snd 10 & \\
\hline \multirow{3}{*}{1} & fenstant & $7.0 \%$ & 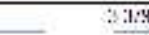 & \\
\hline & Erowd_mugy" & 204 & .078 & 拜 \\
\hline & Kualites_Peloysun & 475 & 057 & . 68 \\
\hline
\end{tabular}

Dependent Variable: Kepuasan Pelanggan Sumber: hasil pengolahan data (SPSS versi 20).

Berdasarkan hasil pengolahan data pada tabel di atas diperoleh persamaan regresi sebagai berikut: $\hat{\mathrm{Y}}=23,022+0,204 \mathrm{X}_{1}+0,475 \mathrm{X}_{2}$, artinya terdapat pengaruh positif antara brand image dan kualitas pelayanan pegawai terhadap kepuasan pelanggan pada Warnet Dimensi Pematangsiantar.

\section{2) Koefisien Korelasi dan Koefisien Determinasi}

Pada tahap ini akan dihitung korelasi berupa derajat atau kedalaman hubungan fungsional yang menjelaskan hubungan antar- perubah, disebut dengan koefisien yang disimbolkan dengan r. Pada uji kali ini dihitung secara keseluruhan antara variabel bebas $X_{1}$ dan $X_{2}$ terhadap variabel terikat. Untuk mengukur seberapa besar variabel bebas menjelaskan variabel terikat maka digunakan koefisien determinasi (KD). Berikut ini adalah hasi uji koefisien korelasi dan koefisien determinasi secara simultan antara variabel bebas Brand Image $\left(\mathrm{X}_{1}\right)$ dan Kualitas Pelayanan $\left(\mathrm{X}_{2}\right)$ dengan variabel terikat Kepuasan Pelanggan (Y). Dengan menggunakan bantuan program SPSS Versi 20, didapatkan hasil perhitungan koefisien korelasi sebagai berikut:

Tabel 3

Hasil Koefisien Korelasi dan Determinasi Model Summary ${ }^{\mathrm{b}}$

\begin{tabular}{|c|c|c|c|c|}
\hline Model & $k$ & \begin{tabular}{c|c|}
$R$ \\
Souan
\end{tabular} & Adjusted K Square & Sta. Limor of the Lst mate \\
\hline 1 & $.54 \sqrt{r}$ & 79 & $m$ & 3.71 \\
\hline
\end{tabular}

b. Dependent Variabel: (Kepuasan Pelanggan)

Sumber: hasil pengolahan data dengan SPSS versi 20

Dari hasil koefisien korelasi pada tabel di atas diperoleh korelasi nilai $\mathrm{r}=0,546$ artinya terdapat hubungan yang sedang dan positif antara brand image dan kualitas pelayanan dengan kepuasan pelanggan pada Warnet Dimensi Pematangsiantar. Diperoleh nilai koefisien determinasi (KD) 0,298 artinya tinggi rendahnya kepuasan pelanggan pada Warnet Dimensi Pematangsiantar sebesar 29,8\% dapat dijelaskan oleh brand image dan kualitas pelayanan, sedangkan sisanya 70,2\% dijelaskan oleh faktor-faktor lain seperti struktur harga, kualitas produk dan dukungan pelanggan.

\section{3) Uji Hipotesis}

\section{a) Uji Simultan (Uji F)}

Pengujian ini dilakukan secara simultan yaitu dilakukan untuk menentukan diterima atau ditolaknya hipotesis, pengujian hipotesis dilakukan untuk mengetahui apakah variabel brand image dan kualitas pelayanan yang diuji berpengaruh terhadap kepuasan pelanggan. Jika tingkat signifikansi $\leq 0,05$ maka $\mathrm{H}_{0}$ ditolak.

Tabel 4

Perkiraan $\mathrm{F}_{\mathrm{hitun}}$

ANOVA ${ }^{a}$

\begin{tabular}{|c|c|c|c|c|c|c|}
\hline & $|M: y| u \mid$ & $\begin{array}{l}\text { Sum of } \\
\text { Squarbe: }\end{array}$ & آل & $\begin{array}{l}\text { Neall } \\
\text { Squary }\end{array}$ & $\mathrm{F}$ & Sig. \\
\hline & Heyession & $1510.9: 1$ & 2 & 5b韭5 & 54.195 & $.0 J^{2}$ \\
\hline 15 & Hasidat & $5: 15$ & 7था & 1.I $: \overline{B i}$ & $x_{-1}$ & 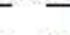 \\
\hline & Tota & $50 x .16$ & 20 & & & \\
\hline
\end{tabular}

a. Dependent Variabel: Kepuasan Pelanggan

b. Predictors: (Constant), Kualitas Pelayanan,

Brand Image

Sumber: hasil pengolahan data dengan SPSS versi 20

Dari hasil analisis pada tabel di atas diperoleh tingkat signifikansi $0,000 \leq \alpha 0,05$ maka $\mathrm{H}_{0}$ ditolak, artinya brand image dan kualitas pelayanan berpengaruh positif dan signifikan terhadap kepuasan pelanggan pada Warnet Dimensi Pematangsiantar secara simultan.

\section{b) Uji Parsial (Uji t)}

Pengujian ini dilakukan secara parsial yaitu dilakukan untuk menentukan diterima atau 
ditolaknya hipotesis, pengujian hipotesis dilakukan untuk mengetahui apakah variabel brand image dan kualitas pelayanan yang diuji berpengaruh terhadap kepuasan pelanggan. Jika tingkat signifikansi $\leq 0,05$ maka $\mathrm{H}_{0}$ ditolak.

Tabel 5

Perkiraan Nilai $t_{\text {hitung }}$ Coefficients $^{\mathrm{a}}$

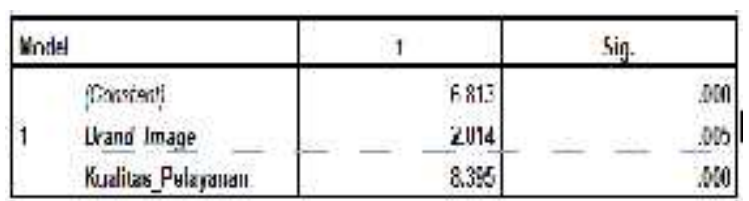

a. Dependent Variabel: Kepuasan Pelanggan

Sumber: hasil pengolahan data dengan SPSS versi 20

Berdasarkan hasil analisis pada table di atas dapat dilihat pada variabel brand image $\left(\mathrm{X}_{1}\right)$ diperoleh signifikansi $0,005 \leq \alpha 0,05$ maka $\mathrm{H}_{0}$ ditolak artinya brand image berpengaruh positif dan signifikan terhadap kepuasan pelanggan Warnet Dimensi Pematangsiantar. Variabel kualitas pelayanan $\left(\mathrm{X}_{2}\right)$ diperoleh signifikansi $0,000 \leq \alpha 0,05$ maka $\mathrm{H}_{0}$ ditolak artinya kualitas pelayanan berpengaruh positif dan signifikan terhadap kepuasan pelanggan Warnet Dimensi Pematangsiantar.

\section{Evaluasi}

\section{a. Brand Image Pada Warnet Dimensi} Pematangsiantar

Untuk Brand image pada Warnet Dimensi Pematangsiantar berdasarkan hasil penelitian dinilai sudah baik.dilihat dari hasil kuesioner yang dibagikan kepada responden mendapat nilai rata-rata keseluruhan sebesar 3,95 dengan kriteria jawaban baik. Namun ada beberapa aspek walaupun dinilai baik tetapi masih ada yang dinilai dibawah rata-rata dari indikator-indikator lain, yang pertama dimensi citra pembuat (corporate image) dengan indikator citra Warnet Dimensi Pematangsiantar memperoleh nilai 3,89 pada kriteria jawaban baik. Untuk mengatasi hal ini sebaiknya Warnet Dimensi Pematangsiantar melakukan perawatan untuk setiap fasilitas yang sudah ada, contohnya selalu memperhatikan kebersihan toilet, melakukan perawatan pada kipas angin dan selalu melakukan pengecekan pada monitor CCTV. Bila terjadi kerusakan agar dapat segera untuk diperbaiki. Pada indikator penilaian pelanggan terhadap Warnet Dimensi Pematangsiantar memperoleh nilai 3,90 dengan kriteria jawaban baik, sebaiknya Warnet Dimensi Pematangsiantar menyediakan jasa yang lainnya seperti menyediakan mesin scanner dan menerima ketikan. Sehingga pelanggan tidak perlu pergi ke tempat lain untuk mendapatkan jasa tersebut.

Untuk dimensi citra pemakai (user image) dengan indikator kesetiaan pelanggan terhadap Warnet Dimensi Pematangsiantar memperoleh nilai 3,89 pada kriteria jawaban baik. Namun, walaupun sudah baik pemilik usaha harus tetap mempertahankan kesetiaan pelanggan dengan memberikan kepuasan baik dari segi kualitas produk, harga dan layanan. Indikator kepercayaan pelanggan 3,93 pada kriteria jawaban baik. Untuk meningkatkan hal ini warnet sebaiknya mempersiapkan pegawai yang mampu bekerja dengan jujur dalam sistem pembayaran (billing) dan pemasangan paket. Indikator mementingkan rasa aman pelanggan 3,92 pada kriteria jawaban baik. Walau sudah pada kategori baik, sebaiknya Warnet Dimensi Pematangsiantar harus tetap memberikan rasa aman pada pelanggan misalnya dengan menyediakan tempat parkir yang luas dan dapat diawasi pegawai juga $C C T V$.

Selanjutnya dimensi citra produk (product image) pada indikator atribut produk yang ditawarkan memperoleh 3,93 dengan kriteria jawaban baik. Sebaiknya melengkapi sarana pendukung untuk bermain games seperti adanya gamepad dan mouse macro. Pegawai juga sebaiknya selalu mengupdate games yang terbaru, agar pelanggan merasa lebih tertarik lagi untuk datang bermain di Warnet Dimensi Pematangsiantar.

Dari evaluasi brand image di atas dapat diambil kesimpulan jika semua hal-hal diatas sudah dinyatakan baik, pelanggan akan merasa puas terhadap brand image yang dimiliki Warnet Dimensi Pematangsiantar. Dengan brand image yang baik maka pelanggan akan tertarik untuk menggunakan jasa tersebut, setelah menggunakan jasa tersebut pelanggan akan merasa puas dan tidak ragu lagi untuk memutuskan menjadi pelanggan tetap.

\section{b. Kualitas Pelayanan Pegawai Pada Warnet \\ Dimensi Pematangsiantar}

Untuk nilai rata-rata dari kualitas pelayanan pegawai sebesar 3,88 dengan kriteria jawaban baik. Namun masih ada beberapa aspek yang masih berada dibawah rata-rata. Pertama pada dimensi bukti fisik (tanggibles) indikator ketersediaan fasilitas penunjang seperti pendingin ruangan Warnet Dimensi Pematangsiantar memperoleh nilai 3,82 dengan kriteria jawaban baik. Dalam hal ini dapat dilihat masih banyak responden yang menyatakan cukup baik atas fasilitas penunjang seperti pendingin ruangan. Sebaiknya Warnet Dimensi Pematangsiantar menambah jumlah kipas angin dalam ruangan sehingga pelanggan merasa nyaman.

Pada dimensi kehandalan (reliability) untuk indikator pegawai Warnet Dimensi Pematangsiantar dalam memberikan pelayanan yang dijanjikan dengan nilai 3,87 dengan kriteria jawaban baik. Sebaiknya Warnet Dimensi Pematangsiantar memberikan pelatihan kepada pegawai terkait dengan pengetahuan mengenai masalah komputer yang sering terjadi saat pelanggan menggunakan komputer. Sehingga pelanggan tidak merasa kecewa pada pegawai. Pada indikator pegawai Warnet Dimensi Pematangsiantar dalam menangani masalah yang dihadapi pelanggan memperoleh nilai 3,75 dengan kriteria jawaban baik. Sebaiknya pemilik Warnet Dimensi Pematangsiantar selalu memberikan pengarahan kepada seluruh pegawainya agar pegawai semakin mampu untuk menangani masalah. 
Pada dimensi daya tanggap (responsiviness) untuk indikator ketanggapan pegawai dalam menanggani masalah pelanggan 3,78 pada kriteria jawaban baik. Walaupun sudah dalam kategori baik Warnet Dimensi Pematangsiantar harus memperbaikinya dengan memberikan pengarahan pada pegawai. Agar pegawai dapat lebih cepat dalam menanggami masalah dan lebih bijak lagi untuk membantu pelanggan. Untuk indikator merespon permintaan pelanggan 3,80 pada kriteria jawaban baik, pegawai sebaiknya mengutamakan kepentingan pelanggan dengan memberikan respon yang cepat untuk memenuhi permintaan pelanggan.

Pada dimensi jaminan (assurances) dengan indikator pengetahuan yang dimiliki pegawai 3,64 dengan kriteria jawaban baik, Warnet Dimensi Pematangsiantar harus meningkatkan kemampuan pegawai dengan memberikan pelatihan terkait dengan sistem dan teknik komputer. Agar pelanggan merasa puas dengan pelayanan yang diberikan pegawai dan pegawai memiliki pengetahuan yang lebih mengenai komputer.

Terakhir dimensi empati (emphaty) pada indikator sikap pegawai dalam menangani keluhan pelanggan 3,82 pada kriteria jawaban baik. Sebaiknya untuk kemajuan usaha sebaiknya pegawai bersikap ramah dan baik dalam menangani keluhan pelanggan sehingga pelanggan tidak lagi merasa sungkan dan tetap menjadi pelanggan di Warnet Dimensi Pematangsiantar. Warnet Dimensi Pematangsiantar juga dapat membuat kotak saran untuk dapat mengetahui apa saja yang dapat diperbaiki dan tetap dipertahankan.

Dalam hal ini dapat dilihat bahwa kualitas pelayanan pada Warnet Dimensi Pematangsiantar sudah dikategorikan baik. Walaupun sudah dalam kategori baik, Warnet Dimensi Pematangsiantar harus tetap memberikan pelayanan yang maksimal dengan menyediakan fasilitas yang lengkap sesuai dengan atribut produk yang ditawarkan, menyiapkan pegawai yang handal, memiliki rasa empati dan daya tanggap yang tinggi sehingga memberikan kepuasan tersendiri kepada pelanggan.

\section{c. Kepuasan Pelanggan Pada Warnet Dimensi \\ Pematangsiantar}

Dari perhitungan rata-rata kepuasan pelanggan diperoleh nilai puas namun ada beberapa aspek yang nilainya masih dibawah rata-rata. Pertama adalah dimensi kualitas produk dengan indikator pegawai Warnet Dimensi Pematangsiantar dalam memberikan penjelasan produk kepada pelanggan dengan nilai 3,77 pada kriteria jawaban puas, untuk mengatasi hal ini pemilik usaha harus melatih pegawainya untuk lebih komunikatif dalam memberikan penjelasan produk pada pelanggan agar pelanggan merasa puas dan mengerti mengenai produk yang ditawarkan. Indikator pegawai Warnet Dimensi Pematangsiantar dalam menjelaskan penggunaan fasilitas 3,81 pada kriteria jawaban puas. Pegawai harus lebih sabar dalam menjelaskan cara penggunaan fasilitas yang tersedia di Warnet Dimensi Pematangsiantar. Pada indikator penawaran produk Warnet Dimensi Pematangsiantar dengan nilai 3,85 dengan kriteria jawaban puas, sebaiknya produk yang ditawarkan tidak hanya berfokus pada games dapat juga didukung dengan menyediakan jasa lain seperti menyediakan mesin scanner dan menerima ketikan.

Pada dimensi harga dengan indikator paket harga pada Warnet Dimensi Pematangsiantar berada pada rata-rata 3,83 dengan kriteria jawaban puas, sebaiknya Warnet Dimensi Pematangsiantar tetap menjaga kepercayaan pelanggan dan mengadakan diskon harga paket pada jam tertentu. Selanjutnya pada dimensi kemudahan Untuk indikator kelengkapan fasilitas pendukung bermain games 3,69 pada kriteria jawaban puas. Sebaiknya Warnet Dimensi Pematangsiantar melengkapi fasilitas pendukung untuk bermain games seperti gamepad dan mouse macro, dengan demikian usaha dapat terus berkembang dengan memenuhi keinginan pelanggan. Indikator jaringan internet 3,59 pada kriteria jawaban puas, untuk memperbaiki hal ini pemilik usaha harus tetap melakukan perawatan secara berkala untuk meminimalisir terjadinya koneksi yang terputus-putus. Maka dengan demikian warnet dalam hal ini dapat memenuhi keinginan pelanggan sehingga pelanggan merasa puas.

\section{KESIMPULAN DAN SARAN}

\section{Kesimpulan}

a. Hasil analisis deskriptif kualitatif tentang brand image nilai rata-rata brand image yang diberikan responden berada pada 3,95 dengan kriteria jawaban baik. Nilai tertinggi 4,17 pada kriteria jawaban baik yaitu pada indikator popularitas Warnet Dimensi Pematangsiantar di masyarakat. Untuk nilai terendah 3,89 dengan kriteria jawaban baik pada dimensi citra pembuat (corporate image) pada indikator citra Warnet Dimensi Pematangsiantar, dan dimensi citra pemakai (user image) pada indikator kesetiaan pelanggan terhadap Warnet Dimensi Pematangsiantar.

b. Hasil analisis deskriptif kualitatif tentang kualitas pelayanan memiliki nilai rata-rata 3,88 dengan kriteria jawaban baik. Rata-rata tertinggi 4,06 dengan kriteria jawaban baik yaitu pada indikator penampilan pegawai Warnet Dimensi Pematangsiantar. Untuk nilai terendah 3,64 pada kriteria jawaban baik pada indikator pengetahuan yang dimiliki pegawai Warnet Dimensi Pematangsiantar.

c. Hasil analisis deskriptif kualitatif tentang kepuasan pelanggan memiliki nilai rata-rata 3,86 dengan kriteria jawaban puas. Untuk nilai ratarata tertinggi sebesar 4,18 dengan kriteria jawaban puas pada dimensi kemudahan dengan indikator letak lokasi Warnet Dimensi Pematangsiantar. Sedangkan nilai rata-rata terendah sebesar 3,59 dengan kriteria jawaban puas pada dimensi kemudahan dengan indikator jaringan internet Warnet Dimensi Pematangsiantar. 
d. Hasil analisis analisis regresi berganda diperoleh $\hat{Y}=23,022+0,204 X_{1}+0,475 X_{2}$, artinya terdapat pengaruh positif antara brand image dan kualitas pelayanan pegawai terhadap kepuasan pelanggan pada Warnet Dimensi Pematangsiantar.

e. Hasil analisis korelasi dan koefisien determinasi dapat dilihat bahwa terdapat hubungan yang sedang dan positif antara brand image dan kualitas pelayanan terhadap kepuasan pelanggan, diperoleh korelasi nilai $r=0,546$ artinya terdapat hubungan yang sedang dan positif antara brand image dan kualitas pelayanan terhadap kepuasan pelanggan pada Warnet Dimensi Pematangsiantar. Diperoleh nilai koefisien determinasi $\mathrm{R}$ 0,298 artinya tinggi rendahnya kepuasan pelanggan pada Warnet Dimensi Pematangsiantar sebesar 29,8\% dapat dijelaskan oleh brand image dan kualitas pelayanan, sedangkan sisanya $70,2 \%$ dijelaskan oleh faktorfaktor lain seperti struktur harga, kualitas produk dan dukungan pelanggan.

f. Hasil uji hipotesis secara simultan dengan uji $\mathrm{F}$

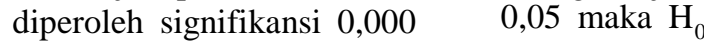
ditolak artinya brand image dan kualitas pelayanan berpengaruh positif dan signifikan terhadap kepuasan pelanggan pada Warnet Dimensi Pematangsiantar secara simultan.

g. Hasil uji hipotesis secara parsial dengan uji $t$ pada brand image $\left(\mathrm{X}_{1}\right)$ diperoleh signifikansi $0,005 \leq \alpha \quad 0,05$ maka $\mathrm{H}_{0}$ ditolak artinya brand image berpengaruh positif dan signifikan terhadap kepuasan pelanggan Warnet Dimensi Pematangsiantar. Variabel kualitas pelayanan $\left(\mathrm{X}_{2}\right)$ diperoleh signifikansi $0,000 \leq \alpha 0,05$ maka $\mathrm{H}_{0}$ ditolak artinya kualitas pelayanan berpengaruh positif dan signifikan terhadap kepuasan pelanggan Warnet Dimensi Pematangsiantar.

\section{Saran}

a. Untuk meningkatkan brand image Warnet Dimensi Pematangsiantar, penulis menyarankan sebaiknya Warnet Dimensi Pematangsiantar melakukan melengkapi sarana dan fasilitas yang dapat mendukung produk yang ditawarkan dan melakukan perawatan secara berkala pada setiap fasilitas yang sudah ada. Seperti pada CCTV, kipas angin, dan menjaga kebersihan toilet.

b. Untuk meningkatkan kualitas pelayanan pegawai Warnet Dimensi Pematangsiantar pemilik usaha sebaiknya pemilik usaha memberikan pelatihan dan arahan pada pegawai agar mampu melayani secara maksimal dan untuk meningkatkan pengetahuan pegawai mengenai komputer. c. Untuk kepuasan pelanggan, penulis menyarankan agar pemilik usaha melengkapi fasilitas yang dibutuhkan pelanggan untuk mendukung produk yang ditawarkan seperti gamepad, mouse macro, perbaikan koneksi jaringan internet, menyediakan tempat parkir yang luas, dan menambah jenis jasa yang ditawarkan dengan menyediakan mesin scanner dan menerima ketikan.

d. Sehubungan dengan keterbatasan-keterbatasan yang ada pada penulis, penelitian ini masih terdapat kelemahan-kelemahan dan belum dapat mengungkapkan seluruh variabel yang dapat mempengaruhi kepuasan pelanggan pada Warnet Dimensi Pematangsiantar. Sebagai bahan masukan untuk penelitian selanjutnya, perlu memperbanyak variabel penelitian, seperti harga, fasilitas, kualitas produk dan lain-lain.

\section{E. DAFTAR PUSTAKA}

Davis, Keith \& John W. Newstrom. 2000. Perilaku Dalam Organisasi. Edisi ketujuh. Jakarta: Erlangga.

Irawan, Handi. 2002. Sepuluh Prinsip Keputusan Pelanggan. Cetakan pertama. Jakarta: Elex media Komputindo.

Kotler, Philip. 2005. Manajamen Pemasaran. Jilid 1 dan 2. Jakarta: PT. Indeks Kelompok Gramedia.

Kotler, Philip dan Kevin lane Keller. 2007. Manajemen Pemasaran. Jilid 1. Edisi 12. Jakarta: PT. Indeks.

Lupiyoadi, Rambat dan Hamdani. 2006. Manajemen Pemasaran Jasa. Jakarta : Salemba Empat.

Setiadi, Nugroho J. 2003. Perilaku Konsumen, Konsep dan Implikasi untuk Strategi dan Penelitian Pemasaran. Jakarta: Prenada Media.

Sumarwan, Ujang. 2003. Perilaku Konsumen, Teori Dan Penerapan Modern, Yogyakarta: Liberty.

Sutisna dan Pawitra. 2001. Perilaku Konsumen dan Komunikasi Pemasaran. Jakarta : PT. Remaja Rosda karya.

Tjiptono, Fandy. 2004. Service Management. Edisi V. Yogyakarta : Andi.

2008. Strategi Pemasaran. Edisi III, Yogyakarta: Andi. 2005. Strategi Pemasaran. Yogyakarta: Andi. 